\title{
The Cognition of Turning Poetry Into Painting
}

\author{
Chih-Long Lin, Jun-Liang Chen, Si-Jing Chen, Rungtai Lin \\ National Taiwan University of Arts, New Taipei City, Taiwan
}

\begin{abstract}
This study used the fuzzy approach to investigate the cognition of emotional responses and visual scenes when turning poetry into painting. In Experiment I, subjects were asked to match a painting with a poetic title based on their emotional responses. Experiment II used a fuzzy rating by which subjects were asked to subjectively evaluate the degree of overall fitness, as well as the degree of fitness between each poem and the emotional responses to and scenes of the paintings. The results show that the fuzzy approach can be applied for the effective evaluation of paintings and can provide artists with an idea of how to concentrate their efforts at the creation stage and improve communication with viewers.
\end{abstract}

Keywords: cognitive ergonomics, picturesque, fuzzy evaluation, semantic cognition

\section{Introduction}

Poetry is a form of verbal art that uses the aesthetic qualities of language. Poetry uses forms and conventions to suggest different interpretations of words or to evoke emotive responses. Poetry has a long history, dating back to the Chinese Shijing (詩經, B.C. 1100-600). Since the mid-20th century, poetry has been more generally regarded as a fundamental creative act employing language. In today's increasingly globalized world, poets often adapt forms, styles, and techniques from diverse cultures and languages (Yeh \& Lin, 2014; Yeh, R. Lin, Wang, \& P. H. Lin, 2014). On the other hand, painting and graphic design are forms of visual art, which is a mode of creative expression consisting of representational, imaginative, or abstract designs produced by the application of color to a two-dimensional surface. Painting as an art form dates back to prehistoric cave paintings (Laude \& Denomme, 1972). In the early 20th century, artists began to experiment with nonrepresentational art, in which formal qualities, such as line, color, and form were explored rather than subject contents. Today, painting vacillates between representational and nonrepresentational forms (Beatty \& Ball, 2010; 2011; Maré, 2010; Beatty, 2011).

Frankel (1957) claimed that in the European Middle Ages, painting was generally regarded as subordinate to literature. During the Italian Renaissance, painters and sculptors attempted to rid themselves of this low reputation. Renaissance artists cited classical authors, such as Simonides of Ceos, who called painting "silent poetry" and poetry "speaking painting". Another favorite quotation was Horace's dictum, "Poetry is like painting". Furthermore, the Italian sculptor and poet Pomponius Gauricus (1841-1530) used the Greek word graphei, meaning both "to write" and "to paint", to prove that these two arts are inseparable. However, Frankel (1957) stated that in the Chinese literary tradition, the Chinese character for "writing" (寫, hsieh) has been used

Chih-Long Lin, Ph.D., assistant professor, Department of Crafts and Design, National Taiwan University of Arts. Jun-Liang Chen, Ph.D. candidate, Graduate School of Creative Industry Design, National Taiwan University of Arts. Si-Jing Chen, Ph.D. candidate, Graduate School of Creative Industry Design, National Taiwan University of Arts. Rungtai Lin, Ph.D., professor, Graduate School of Creative Industry Design, National Taiwan University of Arts. 
in the dual sense of "to write" and "to paint", and that the expression "tu hua" (讀畫), meaning "to look at a painting", literally means "to read a painting". Chinese painting, known as "guóhuà" (國畫), is one of the oldest continuous artistic traditions in the world, and regained popularity in China in the 20th century. Traditionally, Chinese painting involves essentially the same techniques as calligraphy (書法, su huah) and is done with a form of poetry in the painting. The idiom of the "idyllic" (詩情畫意, shiqinghuayi), which literally means a quality suggestive of the poetic and picturesque, is used as the criterion with which to evaluate a Chinese painting (Yeh \& Lin, 2014; Yeh et al., 2014).

A poem creates visual images in the reader's mind, just as a painting creates images in the viewer's eyes. A great painting has much more below the surface than is first seen on the surface. So, it is with poetry. Great art must access the mind as well as the senses. A poem is a painting made with words. The concept of the convertibility of poetry and painting concerns equality, which took many centuries to develop in both Europe and China (Frankel, 1957). In the analysis of poems and paintings, it is important to consider whether or not the texts are situated in the poems in a way that is analogous to the illustrations of the paintings (Laude \& Denomme, 1972). It has been argued that the idea of turning poetry into painting should be interdisciplinary, as well as mentally challenging and creative (Michel, 1999). Maré (2010) explored whether or not visual images and works of art can be "read", and raised important questions as to whether the description and interpretation of a work of visual art can be referred to as the "reading" of that work.

When a viewer is faced with a painting, such as Nana by Monet, he/she is presumably required to interpret the elements provided by decoding and then constructing meaning by encoding. Thus, the audience has to discover or construct a meaning and then attribute that meaning to what is in the painting (Laude \& Denomme, 1972; Antonietti \& Cantoia, 2000). In order to test this general assumption, two experiments were designed to investigate the sense of the poetic and the picturesque in visual images when poetry is turned into painting. The experiments focused on a specific cognitive activity: "reading" the quality of a visual work in terms of the poetic (affection) and the picturesque (scene). While the information processing involved in experiments has been extensively investigated, few studies have approached it from human factors or cognitive psychology perspectives, such as communication theory, mental models, and mental workload (Gentner \& Stevens, 1983; Jakobson, 1987; Hancock \& Meshkati, 1988; Fiske, 1990; Tiedens \& Linton, 2001; Klir, 2005). Therefore, on the basis of previous studies (Leder, Belke, Oeberst, \& Augustin, 2004; Beatty \& Ball, 2010; 2011; Beatty 2011), the purpose of this study was to propose a research framework that contributes to the literature regarding the perceptual process of turning poetry into painting.

Based on previous studies (Barthes, 1967; Silverman, 1984; Jakobson, 1987; Fiske, 1990), a research framework combining communication theory with communication and mental models was proposed to explore the issue of turning poetry into painting, as shown in Figure 1. According to communication theory, an artwork must have three functions in order to express its significance through the symbol system: (a) signification: the artwork expresses a kind of significance - that is, the artist's intentions can be expressed through the artwork; (b) expression: the artwork represents the artist's feelings - that is, through the artwork, the artist's imagination, thoughts, and feelings can be reproduced; and (c) communication: the results of signification and expression can be transmitted to the viewer only when the artist's and the viewer's thoughts are identical (Jakobson, 1987; Fiske, 1990).

In communication theory, three levels of problems are identified in the study of communication: technical, semantic, and effectiveness. The technical level requires letting the addressee receive a message through his/her 
senses, such as seeing, hearing, touching, or even feeling - that is, the ways in which the artist can accurately transmit a message through his/her work. The semantic level requires letting the addressee understand the meaning of the message without misinterpreting, misunderstanding, or not understanding it at all - that is, how precisely the transmitted message expresses the desired meaning. The effectiveness level concerns the ways in which the addressee is made to take the right actions - that is, how effectively does the received meaning affect conduct in the expected way (Fiske, 1990), as shown in Figure 1.

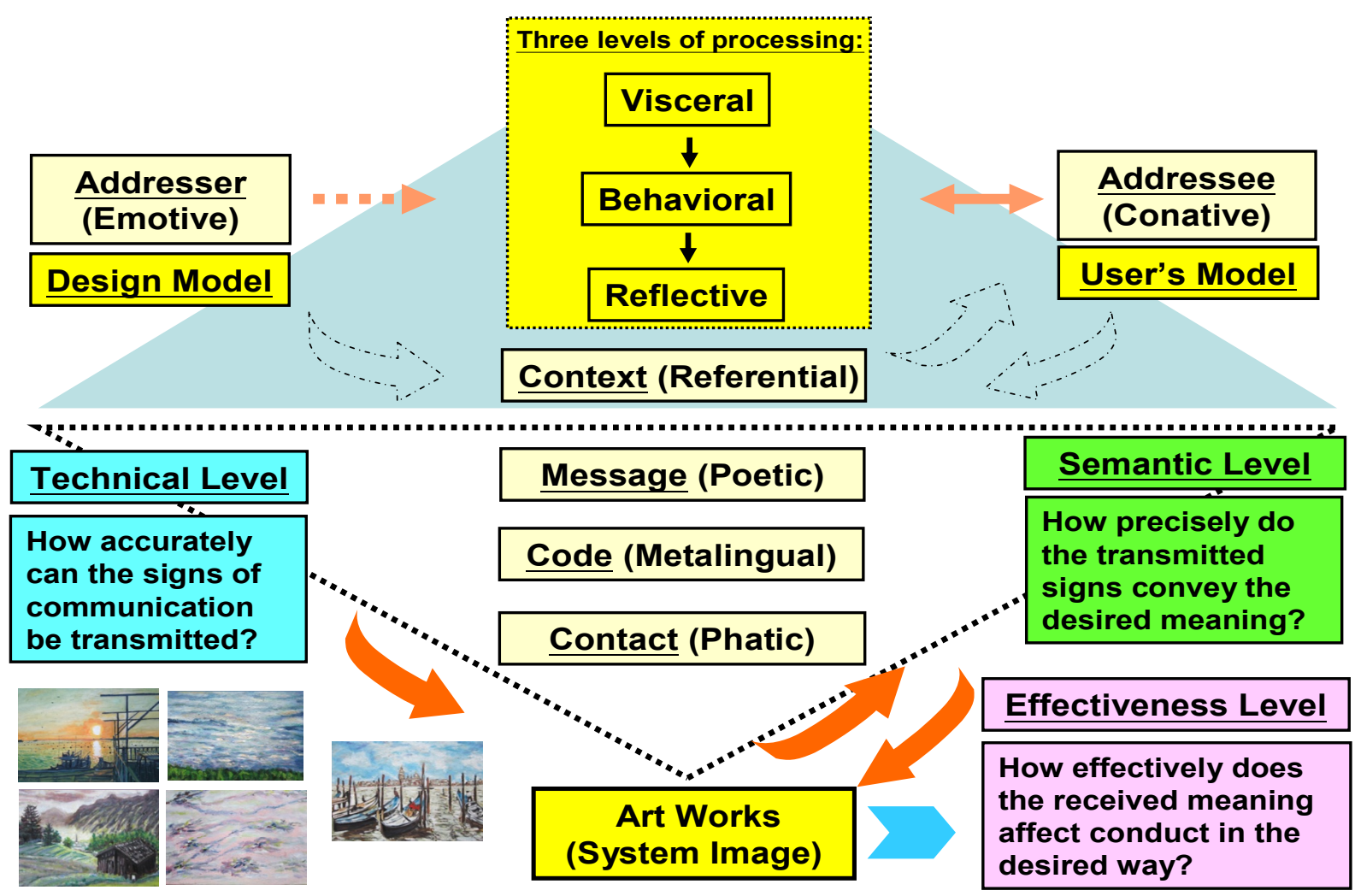

Figure 1. Research framework for turning poetry into painting.

In the communication model, Jakobson (1987) proposed six constitutive factors with six functions in an act of communication. The six constitutive factors are as follows: addresser, addressee, context, message, contact, and code. For example, an artist (addresser) sends a message to an audience (addressee) through his/her artwork. The artist must recognize that his/her work (message) must refer to something other than itself, which is called the background story (context). Then, the artist needs a physical channel and psychological connection between himself/herself and the audience (contact). Finally, his/her message must be based on a shared meaning system (code) by which his/her work is structured. Each of these factors determines a different function in each act of communication: emotive, conative, referential, poetic, phatic, and metalingual. The emotive function communicates the artist's emotions to the audience, whose reaction is a conative function. The referential function is the reality orientation of the message. The other three functions, which may be less familiar, are as follows: The phatic function is to keep the channels of communication open, the metalingual function is to identify the code that is being used, and the poetic function is the relationship of the message to itself, as shown in Figure 1. 
For the mental model of cognitive engineering (Kreifeldt, Lin, \& Chuang, 2011; Yen, C. Lin, \& R. Lin, 2013), Norman (1988) proposed a conceptual model that includes three parts: design model, user's model, and system image. When a designer designs a product for a user, the designer expects that the user will understand and use it in the desired way, meaning that the user's model is identical to the design model. In actuality, the designer should understand the user's mental model, rather than vice versa. The designer always understands his/her own design. The problem is to design a product so that it conforms to the user's mental model. The system image results from the physical structure that has been built by the design model. Because the designer does not talk directly with the user, the communication must take place through the system image. In communication theory, if the message (system image) does not make the design model clear and consistent, the user will end up with the wrong mental model. For emotional design, Norman (2004) proposed three levels of processing - visceral, behavioral, and reflective - which are integrated into Figure 1 as an important part of the research framework.

Turning poetry into painting involves complex issues that are interdisciplinary in nature. This nature appears to be suitable for "reading" in different ways, and multiple perspectives are available through which to analyze them. Based on the above discussion, the research framework can be used in a continuous search for a deeper understanding of the nature of turning poetry into painting, in which some conjectures can be tested.

\section{Method}

In accordance with the research framework (see Figure 1), this study used questionnaires interviews, matching tests, and fuzzy ratings to explore the cognition of turning poetry into painting. Three different sessions were carried out, as shown in Figure 2. Session I included a literature review and the establishment of a research framework. In Session II, a pilot study was conducted, and a matching test approach and fuzzy rating approach were used in formal experiments. In Session III, a confusion matrix, multivariate data, and protocol analysis were applied in order to explore the recognition of turning poetry into paintings. The stimulus, subjects, and procedures are described in detail below.

\section{Stimuli}

The stimuli consisted of the paintings of an amateur painter, Ms. Lee, who has painted for five years. Twenty-one paintings - nine landscape (A-1 to I-9) and 12 abstract (J-10 to U-21) - were selected from Ms. Lee's body of work from the past three years, as shown in Table 1. The nine landscape paintings, which were comprised of nature scenes containing clouds, were used as the base from which the author proposed poetic titles related to clouds. The key factor for the purpose of these poetic titles was that they had to help the audience more easily understand the mood of each painting. Therefore, in creating the titles, the first thing that had to be done was to associate viewers' main visual impressions of the paintings with their life situations. Meanwhile, the poetic titles developed by the author were also recognized by the painter as sufficiently similar to the painter's intentions.

For the abstract paintings, the painter was asked to read the paper entitled "Turning Poetry Into Paintings: An Experiment in Visualization" by Michel (1999) and two related papers (Lin, 2007; Hsu, C. L. Lin, \& R. Lin, 2011). The 12 abstract paintings were then painted according to the selected poetry, following the three steps for turning poetry into paintings: illustration, interpretation, and reaction. The abstract paintings do not contain 
images of specific scenery, objects, or characters; rather, they largely consist of patterns composed of nonobjective colors and lines. The painter developed their poetic titles based on her own creative process and her feelings about the paintings, and focused on whether each poetic title expressed the mood of its painting. Her 21 original poetic titles are listed in Table 2 in the original Chinese and in their English translations.

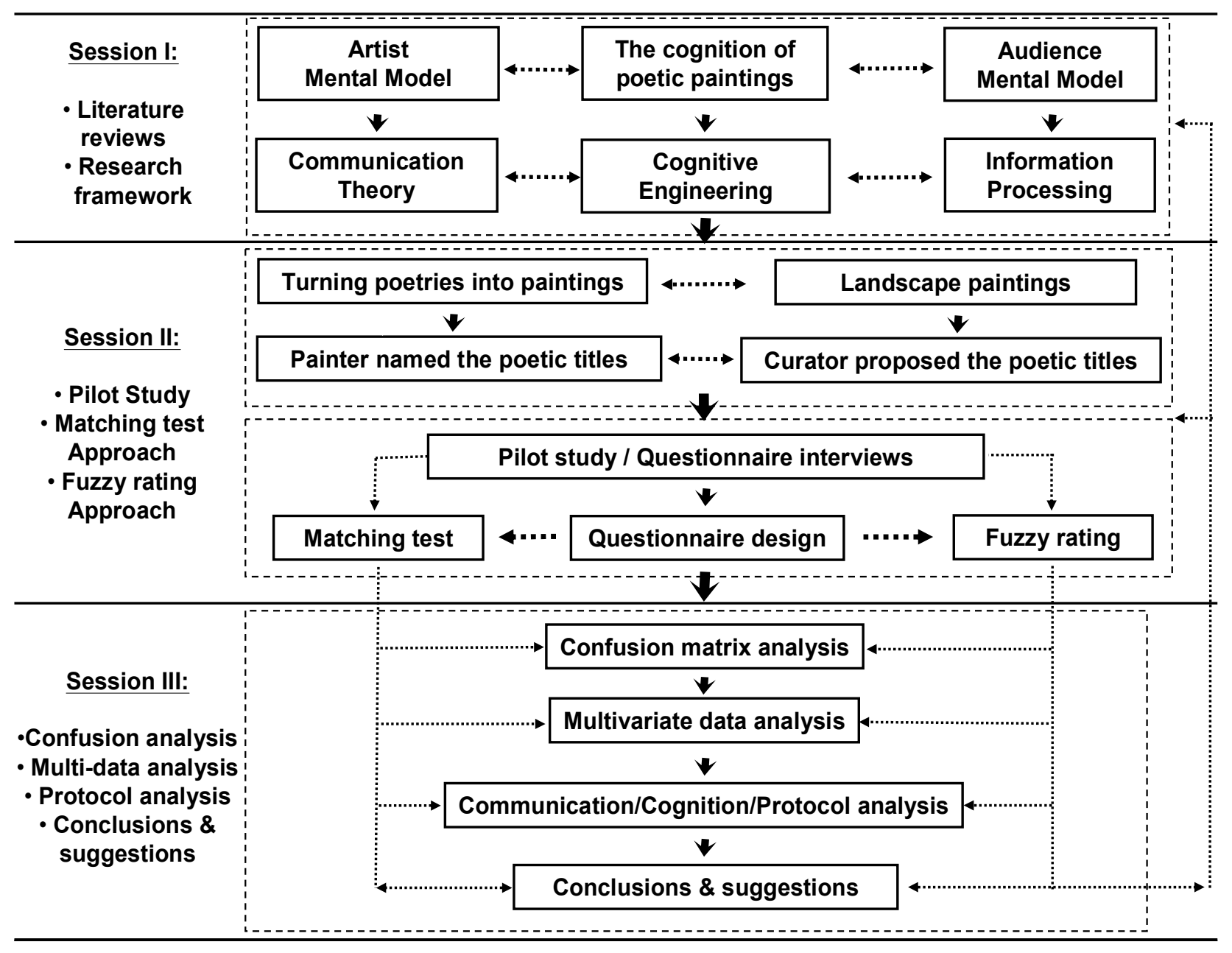

Figure 2. Method for exploring the cognition of turning poetry into painting.

Table 1

Twenty-One Stimulus Paintings

\begin{tabular}{|l|l|l|l|l|l|}
\hline Painting & & & & & \\
\hline
\end{tabular}


(Table 1 to be continued)

\begin{tabular}{|c|c|c|c|c|}
\hline Painting & $\frac{-32}{23}+30$ & 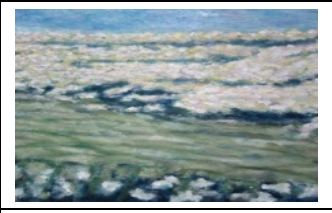 & 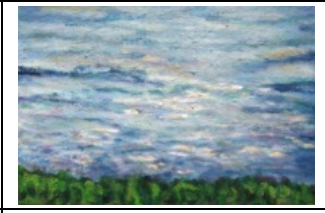 & 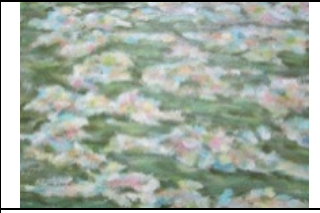 \\
\hline Poetic title in Chinese & I-9：碧雲天芳草無情 & J-10: 大風起合雲飛揚 & K-11: 天光雲影共徘徊 & L-12: 雲想衣裳花想容 \\
\hline Painting & 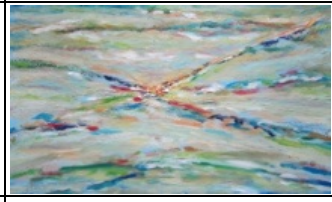 & 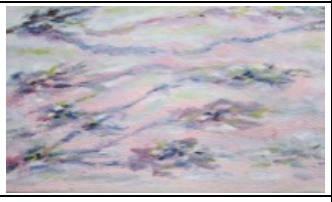 & 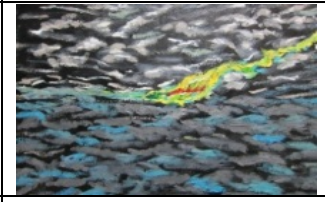 & 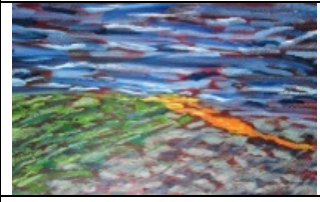 \\
\hline Poetic title in Chinese & M-13: 雲破月來花弄影 & N-14: 去似朝雲無覓處 & O-15: 雲雨巫山露凝香 & P-16: 鴻雁在雲魚在水 \\
\hline Painting & & 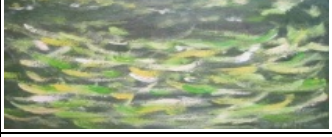 & 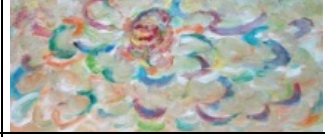 & 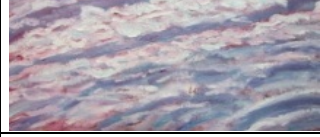 \\
\hline Poetic title in Chinese & Q-17: 來時淡春衣上雲 & R-18: 坐看山窮雲起時 & S-19: 嬌雲春鶯容易飛 & T-20: 朝辭白帝彩雲間 \\
\hline Painting & 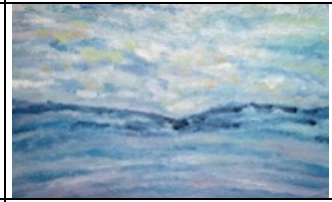 & & & \\
\hline Poetic title in Chinese & U-21: 行雲有影月含羞 & & & \\
\hline
\end{tabular}

\section{Table 2}

The Poetic Titles of the Study Paintings

\begin{tabular}{|c|c|c|}
\hline No. & Chinese poetry & English translation \\
\hline A-1 & 江闊雲低故人歸 & The wide river was dappled with lowing clouds, where an old friend of mine is returning. \\
\hline B-2 & 雲日相輝映萬里 & The cloud and the sun reflect each other in the boundless glory. \\
\hline $\mathrm{C}-3$ & 天上浮雲似白衣 & The clouds in the sky look just like white gowns. \\
\hline D-4 & 白雲深處有人家 & Deep in the clouded mountain was a hamlet. \\
\hline E-5 & 白雲千載空悠悠 & The clouds hold the eternal empty skies. \\
\hline F-6 & 晴空萬里雲滿天 & Crystal sky is full of clouds. \\
\hline G-7 & 朝雲春樹溪水流 & Morning clouds and spring trees accompany the rolling steam. \\
\hline $\mathrm{H}-8$ & 連雲盢屋景無限 & With the running clouds the seemingly stacked cottages, the scenery reaches the borderless. \\
\hline $\mathrm{I}-9$ & 碧雲天芳草無情 & As the sky is clear and bright, the grass brings on my sorrow and sadness. \\
\hline $\mathrm{J}-10$ & 大風起合雲飛揚 & The wind blew and rolled up the clouds filling the sky. \\
\hline K-11 & 天光雲影共徘徊 & Reflected sunlight and cloud shadow lingered over and over. \\
\hline L-12 & 雲想衣裳花想容 & Clouds inspired dresses as flowers prompted faces. \\
\hline M-13 & 雲破月來花弄影 & Moonlight burst from the clouds dancing with the shadow of the flowers. \\
\hline $\mathrm{N}-14$ & 去似朝雲無覓處 & It was gone with the dawn clouds. \\
\hline $\mathrm{O}-15$ & 雲雨巫山露凝香 & The mountain was covered with cloud and dew impearling the peonies with aroma. \\
\hline P-16 & 鴻雁在雲魚在水 & Wild geese fly in the cloud high while twin carps wander in the water deep. \\
\hline Q-17 & 來時淡春衣上雲 & A fair lady is stepping down from the clouds in spring. \\
\hline R-18 & 坐看山窮雲起時 & Endless mountains were linked with lifting clouds. \\
\hline S-19 & 嬌雲春鶯容易飛 & Adorable clouds and spring birds are gone and away. \\
\hline $\mathrm{T}-20$ & 朝辭白帝彩雲間 & I set out with a farewell to Bai-Di Town glittered with morning clouds. \\
\hline $\mathrm{U}-21$ & 行雲有影月含羞 & Floating clouds blurred the bashful moon. \\
\hline
\end{tabular}




\section{Participants}

All of the study participants were university student volunteers from the northern and southern regions of Taiwan. A total of 254 participants -63 men and 191 women between the ages of 18 and 21 (88\%) - participated in the study. The participants were told the purpose of the study. They were then asked to match the paintings with the given poetic titles and to rate the fitness of turning the poetry into paintings according to their understanding of the content of each painting. The procedure is described below in detail.

\section{Procedure}

This study was conducted during design-related classroom courses. The students were invited to participate as subjects and agreed to follow the experimental procedure, including the matching test and fuzzy rating. The purpose of the experiment was explained to the subjects and a slide showing the 21 paintings was juxtaposed with a slide of their corresponding poetic titles. The subjects were then asked to follow the procedure to finish each experiment. The experiments were conducted at least one week apart and had no time limit; generally, each subject completed the experiment within 20 minutes (Hsu, Chang, \& Lin, 2013).

The 21 paintings were randomly ordered on a piece of paper, at the bottom of which their corresponding poetic titles were listed. Before the matching test, the subjects were briefed on the purpose and procedure of the study. Subjects were asked to match each painting with a poetic title. One week following the matching tests (Zwaga, 1989; Lin, 1994), each painting and its corresponding poetic title, together with three questions and a rating scale, were put together, as shown in Table 3.

The subjects were told the purpose of the experiment. They were then asked to rate each painting with its poetic title according to the questions. The fit assessment of each painting included three questions. Question 1 explored the degree of overall fitness between the poetry and the paintings, with a score range from $0 \%$ to $100 \%$ - the higher the score, the better the fit. Questions 2 and 3 explored the degree of fitness between the paintings" poetic titles and their "affection" and "scene". A 5-point Likert scale was used to score the responses from 1 ("Very unfit") to 5 ("Very fit").

Table 3

The Fuzzy Ratings of the Fitness of Total Image, Affection, and Scene

\begin{tabular}{|l|l|l|l|l}
$\begin{array}{l}\text { 1. Please rating the fitness of "total image" between the painting and its poetic title "The spring is } \\
\text { coming" }(0-100 \%) .\end{array}$ \\
2. Please rating the fitness of "affection" between the painting and the poetic title "The spring is \\
coming". \\
Very fit $\leftarrow 1 \quad 2 \quad 3 \quad 4 \quad 5 \rightarrow$ Very unfit \\
3. Please rating the fitness of "scene" between the painting and the poetic title "The spring is coming". \\
Very fit $\leftarrow 1 \quad 2 \quad 3 \quad 4 \quad 5 \rightarrow$ Very unfit
\end{tabular}

\section{Results}

\section{Confusion Between Poetic Titles and Paintings}

In order to evaluate pictorial symbols, many studies have used matching tests to create a confusion matrix, which is then interpreted subjectively by examining it. The matching test in this study revealed the confusion among the paintings and their referents within a stimulus set. Table 4 summarizes the percentage of correct responses and the confusion matrix from the matching test. The main diagonal shows the correct matching (\%) of each poetic title with its painting. In order to easily study the confusion matrix, matching rates under $6 \%$ were ignored. The mismatches between the poetic titles and the other 20 paintings in the set are given in the 
row, while the column shows to what degree the painting was mismatched with the other 20 poetic titles. In the diagonal of the confusion matrix, painting $(\mathrm{G})$ in the landscape group had the highest matching rate at $49 \%$, while painting $(\mathrm{N})$ in the abstract group had the lowest matching rate at $6 \%$.

In the landscape group, paintings (G) and (D) had relatively high matching rates, at $49 \%$ and $43 \%$, respectively; these two paintings are both highly interpretable in their subject and not easily confused with other paintings. Paintings (B) and (H) had middle matching rates, at $34 \%$ and $33 \%$, respectively, while the other five paintings had matching rates of under $30 \%$. In the abstract group, painting (L) had a middle matching rate at $31 \%$, while the other paintings were classified at low matching rates. The paired t-test results show that the average matching rate for the landscape paintings $(27 \%)$ was significantly higher than that of the abstract paintings (16\%) $(t=2.42 ; p<0.05)$.

Table 4 also conveys information on symmetric and asymmetric confusion. Symmetric confusion occurred when subjects mistook two paintings for each other. For example, paintings (A) and (B) were mutually confused at rates of $11 \%$ and $24 \%$, as shown in the first dotted square in Table 5. Paintings $(\mathrm{C})$ and $(\mathrm{H})$ were also confused with each other: painting (C) was correctly matched with poetic title (3) $12 \%$ of the time, but was mismatched $33 \%$ of the time with poetic title (8). Likewise, painting $(\mathrm{H})$ was correctly matched $33 \%$ of the time with poetic title (8) and was mismatched $4 \%$ of the time with poetic title (3). Asymmetric confusion was caused by subjects matching an incorrect poetic title to a given painting. For example, painting (C) was correctly matched with poetic title (3) $12 \%$ of the time and was mismatched at a rate of $10 \%$ with poetic title (4), while painting (D) was correctly matched with poetic title (4) at a rate of $43 \%$, but was never mismatched with poetic title (3).

Table 4

Confusion Matrix With Matching Rates (\%)

\begin{tabular}{|c|c|c|c|c|c|c|c|c|c|c|c|c|c|c|c|c|c|c|c|c|c|}
\hline & \multicolumn{9}{|c|}{ Landscape paintings } & \multicolumn{12}{|c|}{ Abstract paintings } \\
\hline & A & B & $\mathrm{C}$ & $\mathrm{D}$ & $E$ & $\mathrm{~F}$ & $\mathrm{G}$ & $\mathrm{H}$ & I & $\mathrm{J}$ & $\mathrm{K}$ & $\mathrm{L}$ & M & $\mathrm{N}$ & $\mathrm{O}$ & $\mathrm{P}$ & $\mathrm{Q}$ & $\mathrm{R}$ & $S$ & $\mathrm{~T}$ & $\mathrm{U}$ \\
\hline 1 & 27 & 11 & 7 & 9 & 9 & 6 & & 11 & & & & & & & & & & & & & \\
\hline 2 & 24 & 34 & & & & & & & 8 & & & & & & & & & & & & \\
\hline 3 & & & 12 & 0 & & 9 & & (4) & & 7 & 6 & & & 10 & & & & & & 16 & 9 \\
\hline 4 & & & 10 & 43 & & 15 & & 13 & & & & & & & & & & 0 & & & \\
\hline 5 & & & & & 11 & 16 & & 6 & 8 & & 10 & & & & & & & & & 7 & 13 \\
\hline 6 & & & 11 & & 9 & 15 & & 7 & 24 & & 6 & & & & & & & & & & 7 \\
\hline 7 & & & & & & & 49 & & & 8 & & & & 0 & 7 & 7 & & & & & \\
\hline 8 & & & 33 & & & & & 33 & & & & 0 & & & & & & & & & \\
\hline 9 & & & & & & & & & 17 & 11 & 14 & 9 & & & & & & 20 & & & \\
\hline 10 & & & & & 6 & & & & 6 & 16 & & & & 7 & 13 & & & 6 & & 10 & 6 \\
\hline 11 & 7 & 8 & & & & & & & 6 & & 18 & & 14 & & & 7 & & & & & 6 \\
\hline 12 & & & & & & & & $(0)$ & & 7 & & (31) & 4 & 6 & & & 7 & & 28 & & \\
\hline 13 & & & & & & & & & & 7 & & 11 & 15 & 9 & 7 & & 7 & 6 & 13 & & \\
\hline 14 & 6 & & & & 7 & 7 & 0 & 7 & & 6 & 6 & & & 6) & 7 & & 6 & & & 7 & \\
\hline 15 & & & & 8 & & & & & & 6 & & & & 4 & 22 & 8 & & 10 & & & 7 \\
\hline 16 & 9 & 10 & & & (16) & & & & & & & & & & 9 & 14 & & 8 & & & 6 \\
\hline 17 & & & & & & & 8 & & & & & 9 & 7 & 9 & & & 16 & 6 & 6 & 6 & \\
\hline 18 & & & & 22 & & 6 & & & 7 & 6 & & & & & & 7 & 2 & 7 & & & 8 \\
\hline 19 & & & & & & & 9 & & & & & 8 & & 11 & & & 10 & 6 & (19) & & \\
\hline 20 & & 8 & 0 & & & & & & & & & & 13 & 10 & & & 11 & & 6 & 12 & 3 \\
\hline 21 & & & & & & & & & & & 6 & & & 6 & 8 & 13 & 9 & 9 & 6 & 7 & 13 \\
\hline
\end{tabular}


Table 5

Symmetric and Asymmetric Confusions Among the Landscape Paintings

\begin{tabular}{|c|c|c|c|c|c|c|c|c|c|}
\hline & A & B & C & D & $\mathrm{E}$ & F & $\mathrm{G}=0$. & $\mathrm{H}$ & beo. \\
\hline 1. 江闊雲低故人歸 & 0.27 & 0.11 & 0.07 & 0.09 & 0.09 & 0.06 & 0.03 & 0.11 & 0.00 \\
\hline 2. 雲日相輝映萬里 & 0.24 & 0.34 & 0.02 & 0.00 & 0.04 & 0.02 & 0.01 & 0.02 & 0.08 \\
\hline 3. 天上浮雲似白衣 & $0.0 \Gamma$ & $0.02-$ & $0 . \overline{12}$ & $0.00^{\circ}$ & $0.0 \overline{4}$ & $0 . \overline{09}$ & 0.01 & $0 . \overline{04}$ & $\overline{0.06}$ \\
\hline 4. 白雲深處有人家 & 0.00 & 0.00 & 0.10 & 0.43 & 0.04 & 0.15 & 0.01 & 0.13 & 0.02 \\
\hline 5. 白雲千載空悠悠 & 0.01 & 0.01 & 0.04 & 0.01 & $0 . \overline{11}$ & $\overline{0.16}$ & $1_{0.01}$ & 0.06 & 0.08 \\
\hline 6. 晴空萬里雲滿天 & 0,02 & 0.02 & 0.11 & 0.01 & 0.09 & 0.15 & 0.02 & 0.07 & 0.24 \\
\hline 7. 朝雲春樹溪水流 & 0.00 & 0.01 & 0.04 & 0.02 & 0.02 & 0.01 & 0.49 & 0.01 & 0.01 \\
\hline 8. 連雲盢屋景無限 & 0.02 & 0.00 & 0.33 & 0.05 & 0.03 & 0.05 & 0.03 & 0.33 & 0.01 \\
\hline 9. 碧雲天芳草無情 & 0.00 & 0.01 & $\overline{0.01}$ & 0.01 & $0 . \overline{02}$ & 0.01 & $0 . \overline{01}$ & $\overline{0.01}$ & 0.17 \\
\hline
\end{tabular}

Table 6 shows the confusions among the abstract paintings. The most significant symmetric pairs are shown along the main diagonal, while the asymmetric confusions are shown in the circled matching rates off the main diagonal. Among the symmetric pairs, paintings $(\mathrm{O})$ and $(\mathrm{P})$ were mutually confused at rates of $8 \%$ and 9\%, respectively, as shown in Table 6. Paintings (S) and (L) were also symmetrically confused: painting (S) was correctly matched with poetic title (19) $19 \%$ of the time and was mismatched $28 \%$ of the time with poetic title (12), while painting (L) was correctly matched with poetic title (12) $31 \%$ of the time and was mismatched $8 \%$ of the time with poetic title (19). Among the asymmetric confusions, painting (R) had a correct matching rate of $7 \%$ with poetic title (18) and was mismatched at a rate of $6 \%$ with poetic title (19), while painting (S) had a correct matching rate of $19 \%$ with poetic title (19), but was not mismatched with poetic title (18).

Table 6

Symmetric and Asymmetric Confusions Among the Abstract Paintings

\begin{tabular}{|c|c|c|c|c|c|c|c|c|c|c|c|c|}
\hline & J & $\mathrm{K}$ & $\mathrm{L}$ & $\mathrm{M}$ & $\mathrm{N}$ & $\mathrm{O}$ & $\mathrm{P}$ & $\mathrm{Q}$ & $\mathrm{R}$ & $\mathrm{S}$ & $\mathrm{T}$ & $\mathrm{U}$ \\
\hline 10. 大風起合雲飛揚 & 0.16 & 0.04 & 0.04 & 0.03 & 0.07 & 0.13 & 0.06 & 0.03 & 0.06 & 0.02 & 0.10 & 0.06 \\
\hline 11. 天光雲影共徘䧃 & 0.02 & 0.18 & 0.04 & 0.14 & 0.05 & 0.03 & 0.07 & 0.04 & 0.04 & 0.02 & 0.04 & 0.06 \\
\hline 12. 雲想衣裳花想容 & 0.07 & 0.01 & 0.31 & 0.04 & 0.06 & 0.00 & 0.01 & 0.07 & 0.02 & 0.28 & 0.04 & 0.01 \\
\hline 13. 雲破月來花弄影 & 0.07 & 0.03 & 0.11 & 0.15 & 0.09 & 0.07 & 0.04 & 0.07 & 0.06 & 0.13 & 0.03 & 0.02 \\
\hline 14. 去似朝雲無覓處 & 0.06 & 0.06 & 0.01 & 0.04 & 0.06 & 0.07 & 0.05 & 0.06 & 0.02 & 0.02 & 0.07 & 0.05 \\
\hline 15. 雲雨巫山露凝香 & 0.06 & 0.04 & 0.04 & 0.05 & 0.04 & 0.22 & 0.08 & 0.04 & 0.10 & 0.03 & 0.04 & 0.07 \\
\hline 16. 鴻雁在雲魚在水 & 0.02 & 0.04 & 0.03 & 0.02 & 0.04 & 0.09 & 0.14 & 0.02 & 0.08 & 0.02 & 0.04 & 0.06 \\
\hline 17. 來時淡春衣上雲 & 0.05 & 0.02 & 0.09 & 0.07 & 0.09 & 0.02 & 0.03 & 0.16 & 0.06 & 0.06 & 0.06 & 0.01 \\
\hline 18. 坐看山窮雲起時 & 0.06 & 0.04 & 0.01 & 0.02 & 0.01 & 0.05 & 0.07 & 0.02 & $0.0 \%$ & 0.00 & 0.03 & 0.08 \\
\hline 19. 嬌雲春鶯容易飛 & 0.04 & 0.00 & 0.08 & 0.05 & 0.11 & 0.02 & 0.05 & 0.10 & 0.06 & 0.19 & 0.03 & 0.03 \\
\hline 20. 朝辭白帝彩雲間 & 0.04 & 0.02 & 0.03 & 0.13 & 0.10 & 0.03 & 0.04 & 0.11 & 0.02 & 0.06 & 0.12 & 0.03 \\
\hline 21. 行雲有影月含羞 & 0.01 & 0.06 & 0.01 & 0.04 & 0.06 & 0.08 & 0.13 & 0.09 & 0.09 & 0.06 & 0.07 & 0.13 \\
\hline
\end{tabular}

\section{Fuzzy Ratings of Poetic Titles and Paintings}

The application of the fuzzy approach is widespread in various fields, from behavioral and social science to product design and human factors (Lin, 1994). Fuzzy rating allows respondents to provide an imprecise rating that takes into account the reality of the imprecision of human thoughts (Carlesson \& Fullér, 2003). 
Table 7 summarizes the fuzzy rating of the total image, affection, and scene between poetic titles and paintings. The second column indicates the percentage of correct matches for each painting. Among the landscape paintings, the average fitness of total image was $73.6 \%$, while the average fitness of affection and scene were both 3.5. Painting (D) with poetic title (4) and painting $(\mathrm{G})$ with poetic title (7) had the highest average fitness of total image at $82 \%$ and $81.3 \%$, respectively, while the average fitness of affection and scene between poetic titles and paintings were both 4.0 for D-4 and were 3.9 and 4.1, respectively, for G-7. Meanwhile, pairs C-3 and E-5 had the lowest average fitness for total image at $63.2 \%$ and $63.6 \%$, respectively, while the average fitness of affection and scene were both 2.9 for C-3 and were 3.0 and 2.9, respectively, for E-5. The other five title/painting pairs had a high average fitness of between $70 \%$ and $80 \%$ for total image, and a low fitness for both affection and scene.

Table 7

Summary of Correct Matching Rates With Fuzzy Rating Data (Mean and Standard Deviation)

\begin{tabular}{|c|c|c|c|c|c|}
\hline \multirow{2}{*}{$\begin{array}{l}\text { Painting } \\
\text { pairs }\end{array}$} & & \multirow{2}{*}{$\frac{\text { Matching test }}{\text { Correct rates }(\%)}$} & \multicolumn{3}{|c|}{ Fuzzy rating } \\
\hline & & & Total image $(S D)$ & Affection $(S D)$ & Scene $(S D)$ \\
\hline \multirow{9}{*}{$\begin{array}{l}\text { Landscape } \\
\text { paintings }\end{array}$} & A-1 & 27 & $78.0(7.13)$ & $3.8(0.97)$ & $3.8(1.04)$ \\
\hline & B-2 & 34 & $76.9(15.48)$ & $3.7(0.88)$ & $3.7(0.96)$ \\
\hline & $\mathrm{C}-3$ & 12 & $63.2(21.37)$ & $2.9(1.03)$ & $2.9(1.08)$ \\
\hline & D-4 & 43 & $82.0(14.55)$ & $4.0(0.93)$ & $4.0(0.93)$ \\
\hline & E-5 & 11 & $63.6(18.58)$ & $3.0(0.80)$ & $2.9(0.94)$ \\
\hline & F-6 & 15 & $70.8(19.14)$ & $3.4(0.93)$ & $3.3(1.08)$ \\
\hline & G-7 & 49 & $81.3(13.28)$ & $3.9(0.81)$ & $4.1(0.84)$ \\
\hline & $\mathrm{H}-8$ & 33 & $71.6(19.35)$ & $3.4(1.01)$ & $3.5(1.05)$ \\
\hline & I-9 & 17 & $75.3(17.07)$ & $3.6(1.03)$ & $3.7(1.01)$ \\
\hline \multirow{12}{*}{$\begin{array}{l}\text { Abstract } \\
\text { paintings }\end{array}$} & $\mathrm{J}-10$ & 16 & $68.3(20.62)$ & $3.3(1.01)$ & $3.3(1.09)$ \\
\hline & K-11 & 18 & $77.2(14.86)$ & $3.7(0.87)$ & $3.7(0.97)$ \\
\hline & $\mathrm{L}-12$ & 31 & $75.1(14.44)$ & $3.6(0.87)$ & $3.6(0.96)$ \\
\hline & M-13 & 15 & $64.9(18.12)$ & $3.2(0.90)$ & $3.0(0.96)$ \\
\hline & $\mathrm{N}-14$ & 6 & $66.3(20.85)$ & $3.1(0.97)$ & $3.0(1.09)$ \\
\hline & $\mathrm{O}-15$ & 22 & 65.5 (21.67) & $3.1(1.04)$ & $3.0(1.12)$ \\
\hline & P-16 & 14 & $64.0(21.93)$ & $3.0(1.06)$ & $2.9(1.11)$ \\
\hline & Q-17 & 16 & $69.8(17.62)$ & $3.3(0.90)$ & $3.2(1.03)$ \\
\hline & $\mathrm{R}-18$ & 7 & $55.2(24.13)$ & $2.6(0.98)$ & $2.5(1.02)$ \\
\hline & S-19 & 19 & $64.4(20.36)$ & $3.1(0.92)$ & $2.9(1.00)$ \\
\hline & $\mathrm{T}-20$ & 12 & $73.1(18.43)$ & $3.5(0.93)$ & $3.4(0.99)$ \\
\hline & $\mathrm{U}-21$ & 13 & $66.3(18.94)$ & $3.2(0.89)$ & $3.0(0.98)$ \\
\hline
\end{tabular}

A stepwise multiple regression analysis was used to establish the regression model's total image fitness for the landscape paintings. The results are as follows:

Total image fitness (Landscape paintings) $=12.82+0.73$ (Affection fitness) +0.28 (Scene fitness)

Equation (1)

$$
\text { (Adjusted } R^{2}=0.98 ; p<0.001 \text { ) }
$$

The participants' gender and age and the title development method for the paintings were not entered into the model, so the overall fit was mainly affected by scene fit and affection fit. The higher the scene and affection fits were, the higher the overall fit was for landscape painting.

Among the abstract paintings, the overall average fitness of total image, affection, and scene were $67.5 \%$, 
$3.2 \%$, and $3.1 \%$, respectively. The three title/painting pairs $\mathrm{K}-11, \mathrm{~L}-12$, and $\mathrm{T}-20$ had high total image fitness ratings of $77.2 \%, 75.1 \%$, and $73.1 \%$, respectively, while the fitness of their affection and scene were all higher than 3.5. The lowest fitness of total image was pair R-18 at only $55.2 \%$, while its fitness of affection and scene were 2.5 and 2.6. The other eight pairs had an average total image fitness rating of between $60 \%$ and $70 \%$, with low affection and scene fitness ratings of between 3.0 and 3.5. A stepwise multiple regression analysis was applied to establish the regression model's total image fitness for the abstract paintings. The results are as follows:

Total image fitness (Abstract paintings) $=13.14+0.98$ (Scene fitness)

Equation (2)

$$
\text { (Adjusted } R^{2}=0.96 ; p<0.001 \text { ) }
$$

The participants' gender and age and the title development method for the paintings were not entered into the model, so the overall fit was mainly affected by the affection fit: the higher the affection fit, the higher the overall fit.

\section{Discussion}

\section{Avoiding Confusion on Three Levels}

Table 8 shows three different groups that were created based on correct matching rate and total image rating. Five paintings that had a correct matching rate of more than $30 \%$ and a total image fitness of more than $70 \%$ were classified into the "high recognition" group. Nine paintings with a correct matching rate of less than $30 \%$ and a total image fitness rate of more than $70 \%$ were classified into the "middle recognition" group. The other seven paintings were classified into the "low recognition" group, as shown in Table 8.

Table 8

Summary of High, Middle, and Low Recognition Groups

\begin{tabular}{lll}
\hline \multirow{2}{*}{ Correct matching rate } & \multicolumn{2}{c}{ Total image fitness } \\
\cline { 2 - 3 } & $>70 \%$ & $<70 \%$ \\
\hline$>30 \%$ & B-2, D-4, G-7, H-8, and L-12 & - \\
$<30 \%$ & A-1, F-6, I-9, J-10, K-11, N-14, Q-17, T-20, and U-21 & C-3, E-5, M-13, O-15, P-16, R(18), S(19) \\
\hline
\end{tabular}

Several symmetric and asymmetric confusions are summarized in Table 9 . For example, in the symmetric confusion of A-1 and B-2, poetic title (1) was correctly chosen for painting (A) $27 \%$ of the time and was mismatched $24 \%$ of the time when poetic title (2) was presented, while painting (B) was mismatched $11 \%$ of the time with poetic title (1) and was correctly matched $34 \%$ of the time with poetic title (2).

Most of the symmetric and asymmetric confusion pairs occurred at the technical, semantic, and effectiveness levels of the communication model, as shown in Figure 1. These confusions were grouped into three types based on the following three problems:

1. Visual similarity is a technical level that focuses on denotative elements. Visual confusion mostly occurred in landscape paintings; for example, A-1 and B-2 shared the visual feature of a "wide river" and an "ocean", while E-5 and F-6 had similar backgrounds involving "clouds hanging in the sky".

2. Conceptual similarity is a semantic level that concerns connotative content. Conceptual confusion was caused because of a lack of reference for an event or image, especially in abstract paintings; for example, L-12 and M-13 were confused with each other, as were N-14 and O-15, because they turned poetry about clouds into abstract paintings with no specific visual features as referents for decoding. Consequently, the audience created the beautiful world of these paintings in their imaginations. This is the reason why abstract paintings 
experienced low recognition of their diversity.

3. Visual and conceptual similarity is an effectiveness level that conveys meaning to the audience in the desired way. Visual and conceptual confusion is caused by the visual and verbal similarity. For example, the titles of I-9 and J-10 contained the words "cloud" and "mountain", while the visual element of "clouds" appeared in both paintings. Likewise, D-4 and R-18 comprise a typical example of asymmetric confusion: painting (D) was correctly matched at a rate of $43 \%$ with poetic title (4) and was mismatched at a rate of $22 \%$ with poetic title (18), while painting (R) was correctly matched at a rate of $7 \%$ with poetic title (18) but was not mismatched with poetic title (4). Some pairs were not confused with each other. For example, painting (H), with a correct matching rate of $33 \%$, was not confused with painting (L), with a matching rate of $31 \%$.

\section{Table 9}

The Symmetric and Asymmetric Confusion Pairs

\begin{tabular}{|c|c|c|c|}
\hline & $X$ painting & & $Y$ painting \\
\hline & $\begin{array}{l}\text { A-1 }(27 \% ; 24 \%) \\
\text { 1. The wide river was dappled with lowing } \\
\text { clouds, where an old friend of mine is } \\
\text { returning. }\end{array}$ & $+i$ & $\begin{array}{l}\text { B-2 }(11 \% ; 34 \%) \\
\text { 2. The cloud and the sun reflect each other in } \\
\text { the boundless glory. }\end{array}$ \\
\hline yed 16 & $\begin{array}{l}\text { E-5 }(11 \% ; 16 \%) \\
5 . \text { The clouds hold the eternal empty skies. }\end{array}$ & & $\begin{array}{l}\text { F-6 }(9 \% ; 15 \%) \\
\text { 6. Crystal sky is full of clouds. }\end{array}$ \\
\hline & \begin{tabular}{|l}
$\mathrm{L}-12(31 \% ; 11 \%)$ \\
$12 . \quad$ Clouds inspired dresses as flowers \\
prompted faces.
\end{tabular} & +2 & $\begin{array}{l}\text { M-13 }(4 \% ; 15 \%) \\
13 \text {. Moonlight burst from the clouds dancin } \\
\text { with the shadow of the flowers. }\end{array}$ \\
\hline 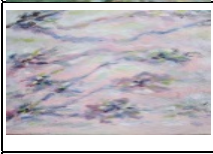 & $\begin{array}{l}\text { N-14 }(6 \% ; 4 \%) \\
\text { 14. It was gone with the dawn clouds. }\end{array}$ & & $\begin{array}{l}\text { O-15 }(7 \% ; 22 \%) \\
(15) \text { The mountain was covered with cloud an } \\
\text { dew impearling the peonies with aroma. }\end{array}$ \\
\hline & $\begin{array}{l}\text { I-9 }(17 \% ; 6 \%) \\
\text { 9. As the sky is clear and bright, the grass } \\
\text { brings on my sorrow and sadness. }\end{array}$ & 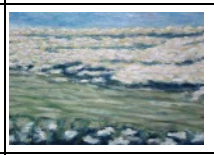 & $\begin{array}{l}\text { J-10 }(11 \% ; 16 \%) \\
10 . \text { The wind blew and rolled up the clou } \\
\text { filling the sky. }\end{array}$ \\
\hline & $\begin{array}{l}\text { D-4 }(43 \% ; 22 \%) \\
\text { 4. Deep in the clouded mountain was a hamlet. }\end{array}$ & 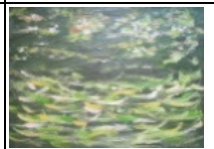 & $\begin{array}{l}\text { R-18 }(0 \% ; 7 \%) \\
18 . \text { Endless mountains were linked with liftin } \\
\text { clouds. }\end{array}$ \\
\hline $\sin ^{2} \sqrt{\frac{1}{12}}$ & $\begin{array}{l}\mathrm{H}-8(33 \% ; 0 \%) \\
8 . \text { With the running clouds the seemingly } \\
\text { stacked cottages, the scenery reaches the } \\
\text { borderless }\end{array}$ & 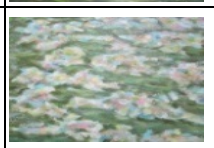 & $\begin{array}{l}\text { L-12 }(0 \% ; 31 \%) \\
12 . \quad \text { Clouds inspired dresses as flowe } \\
\text { prompted faces. }\end{array}$ \\
\hline
\end{tabular}

The main confusions between the paintings and their poetic titles derived from the different natures of visual and verbal codes. Visual codes have a defined, limited paradigm of signifiers with precisely related content and context (Barthes, 1967; Fiske, 1990). They emphasize denotative meaning. Verbal codes have open-ended paradigms: New units can be added and existing ones can drop out of use. They tend not to have an agreed-upon content or context. They are thus more dynamic and capable of change. Visual codes are static and can only change by explicit agreement amongst the audience. Painting codes, then, are closed. They attempt to contain meaning within their visual elements and do not invite the audience to bring much to their side of the negotiating process. All painting codes require that the audience understands their visual features. On the other hand, poetry codes are open and invite the active negotiation of the audience. Extreme types of poetry codes 
can be called aesthetic, and can sometimes be decoded only via clues within the verbal elements (Tiedens \& Linton, 2001; Silvia, 2005; Worringer, 2007).

The difference between visual and verbal code systems is the key factor that causes symmetric and asymmetric confusion. The artist must therefore be sure to select the appropriate visual elements for those paintings in the low recognition group by avoiding asymmetric confusion, and to select the right verbal contents for those in the middle recognition group by preventing symmetric confusion.

\section{The Trade-Offs Between Denotation and Connotation}

A painting of a poetic "scene" denotes that a particular "affection" occurs when the "scene" meets the emotions of the audience and the values of their culture. The "scene" dimension refers to the physical or tangible characteristics of a painting that have an objective basis for comparison. For example, a painting has form, color, layout, and so on. On the other hand, respondents may "subjectively" attach features to a painting. Examples of this include "beautiful", "elegant", and "good-looking". These perceived dimensions are unique to the individual and may bear little correspondence to the objective dimensions of the painting (Reber, Schwarz, \& Winkielman, 2004).

In Experiment II, the respondents were asked to subjectively evaluate the fitness of "scene" and "affection" between a painting and its poetic title. A denotative scene with a connotative affection presented the total image of a painting. Hence, the respondents encountered great difficulties in separately rating the degree of fitness in the objective (scene) and perceived (affection) dimensions. For example, painting (A) with poetic title (1) and painting (B) with poetic title (2) experienced symmetric confusion. Both had the same denotative scenario, containing a "wide river" or "ocean", and had the same affection for a sunrise or a reference to returning home. These caused visual and conceptual confusion. Although the denotative image functions for the individual paintings can convey their intended meanings, when the two paintings were juxtaposed simultaneously, the visual and conceptual confusion decreased the correct matching rates. The denotative meanings of paintings (A) and (B) were the same, while the difference lay in their connotations.

Denotation is the visual transformation in painting of the poetic affection on which the painter is focused. Connotation refers to the audience's process of decoding the transformation made by the painter. Thus, denotation is the way in which a "scene" is painted, while connotation is the way in which "affection" is presented. Some studies have shown that the advantages of shared visual elements lie in the audience having less to learn, and that they may make predictions about important characteristics of unfamiliar situations (Collins \& Lerner, 1983; Barthelemy, Mazur, \& Reising, 1990). However, the present study shows that the advantages of shared denotative elements are not always realized. Figure 3 shows the relationship between affection and scene fitness from respondents' subjective ratings. Subjects tended to rate the fitness of the scene and affection of landscape paintings equally, as shown in regression model (1) and Figure 3, while the fitness of abstract paintings depended mainly on scene, as shown in regression model (2).

For example, painting $(\mathrm{G})$, which had a high correct matching rate $(49 \%)$ in the landscape group, had fitness scores of 3.9 for affection and 4.1 for scene. Painting $(\mathrm{N})$, which had the lowest correct matching rate (6\%), had scores of 3.1 and 3.0, respectively, in the subjective ratings of the fitness of affection and scene. Figure 4 summarizes the distribution of painting $(\mathrm{G})$ with poetic title (7) and painting $(\mathrm{N})$ with poetic title (14). The pairings of paintings $(\mathrm{G})$ and $(\mathrm{N})$ with the 21 poetic titles are shown in the upper part of Figure 4, while the matching of poetic titles (7) and (14) with the 21 paintings are shown at the bottom. Although paintings (G) and 
(N) had the same linear relationship, painting $(\mathrm{G})$ tended toward scene and painting $(\mathrm{N})$ tended toward affection. Painting $(\mathrm{G})$ used trees and a stream as denotative visual elements to represent the scenery of spring, which matches with poetic title (7). In contrast, painting $(\mathrm{N})$ has no specific denotative visual elements for reference, so the subjects evaluated that painting based on the perceived (affection) dimension, causing a mismatch.

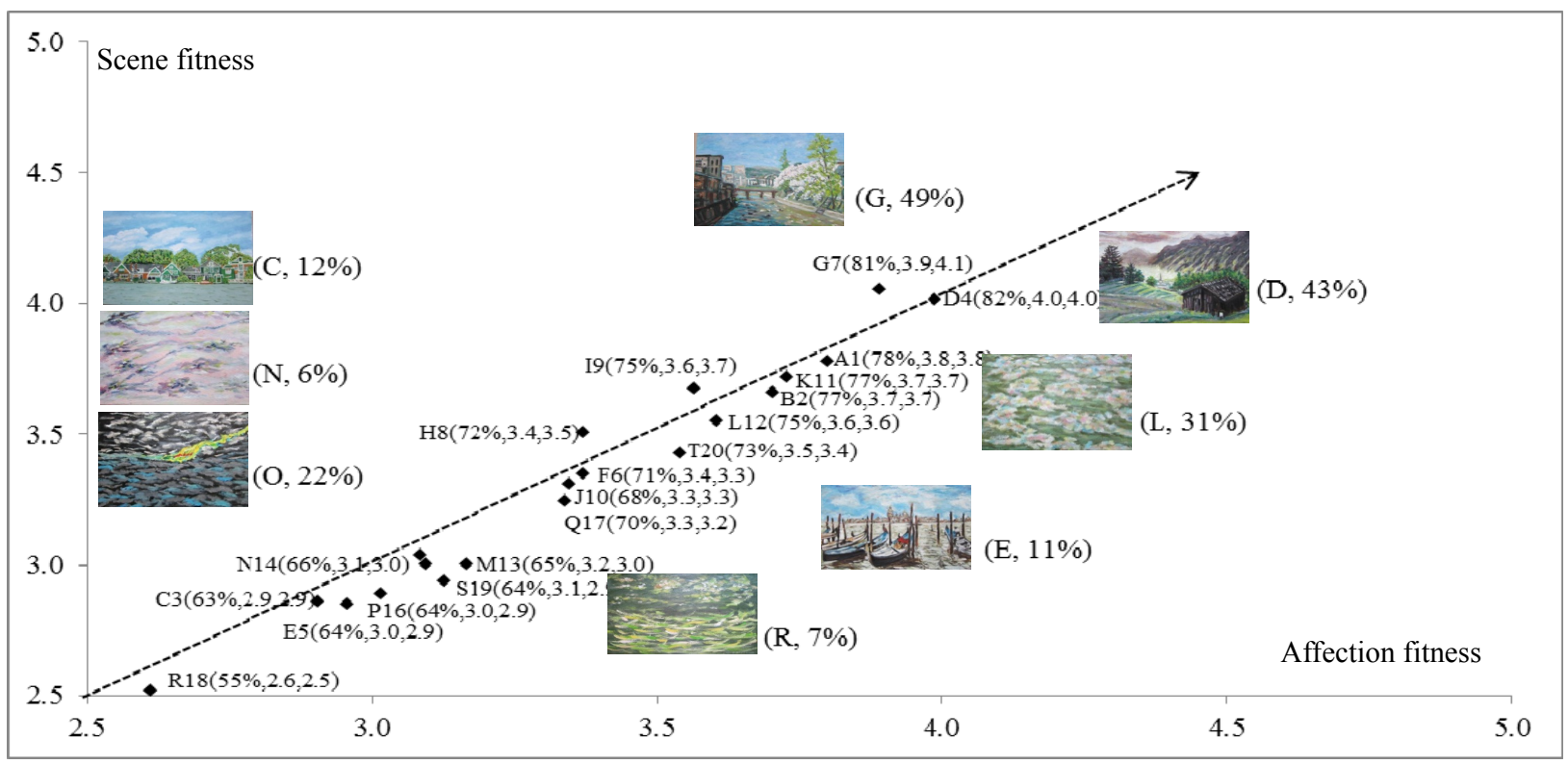

Figure 3. The relationship between affection and scene.

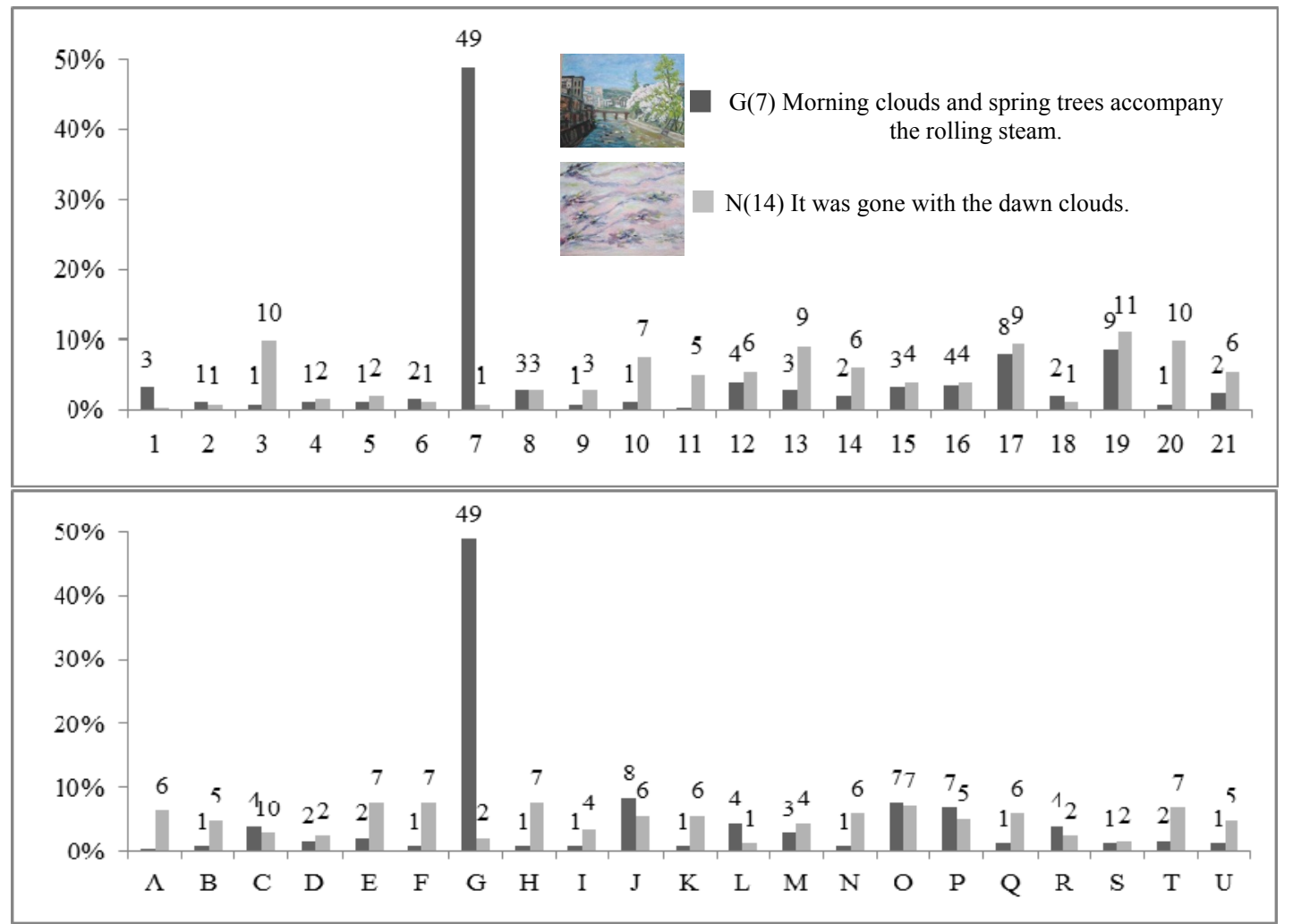

Figure 4. The distribution of paintings $(\mathrm{G})$ and $(\mathrm{N})$ with their poetic titles. 
Figure 5 summarizes the relationship among total image, affection, and scene, based on Table 7. The total image fitness depended on the connotative (affection) and denotative (scene) factors. Therefore, from the artist's point of view, when creating poetic paintings, consideration must be given to focusing on a denotative visual code so that the audience can transfer the connotation of one painting to poem. Yet, paintings with the same visual elements tend to cause symmetric confusion. Therefore, an artist needs to consider the trade-offs between the benefit of conveying connotations of paintings quickly and the cost of creating symmetric confusion.

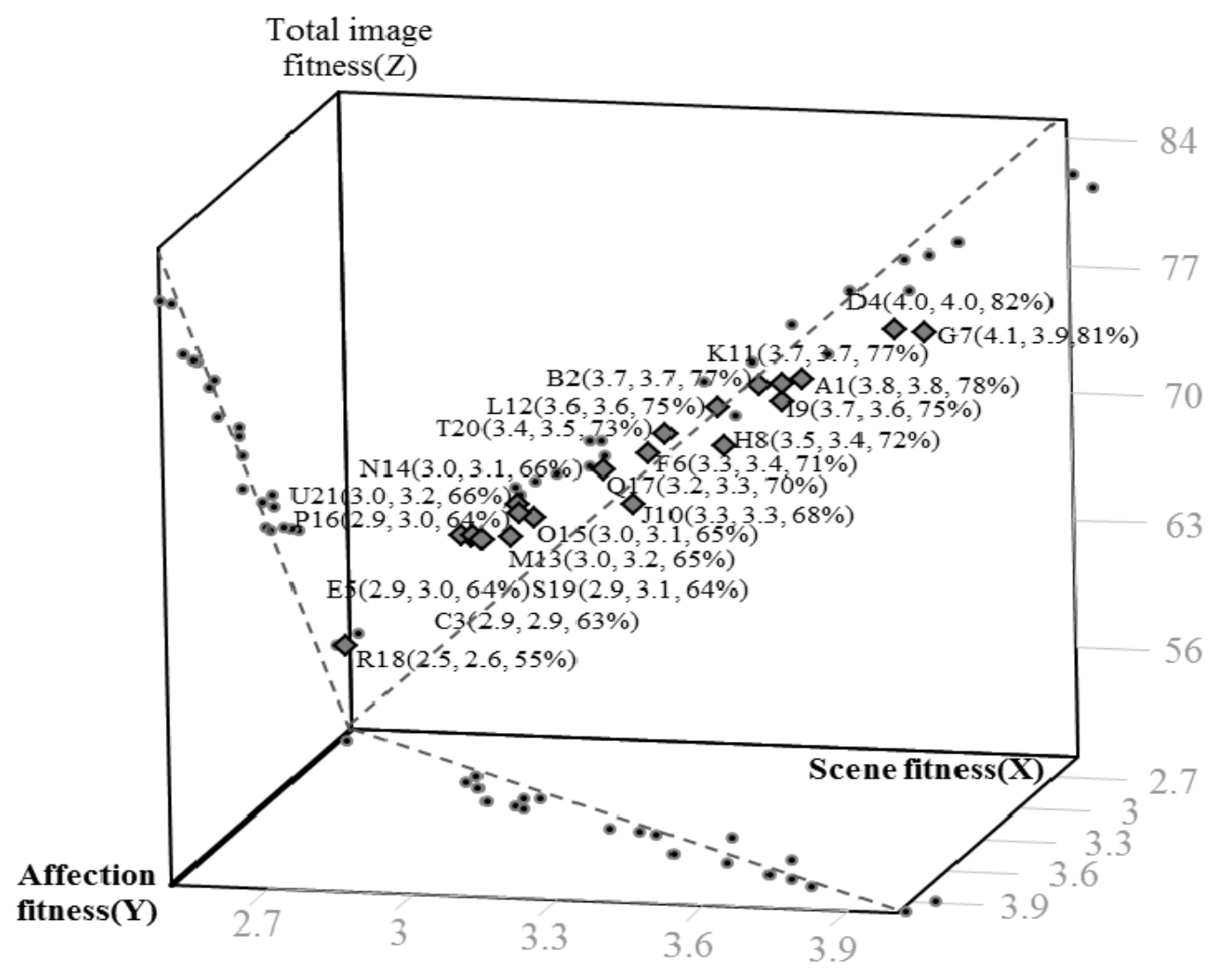

Figure 5. The relationships among total image, affection, and scene fitness.

\section{Conclusion}

Understanding how an audience recognizes a painting is as complex as understanding visual perception itself. Since the cognitive factors that affect the appreciation of paintings have not been properly analyzed, the cognition of turning poetry into painting is typically ill-defined or fuzzy (Belke, Leder, Strobach, \& Carbon, 2010). The purpose of this study was to propose a framework for turning poetry into painting and to use a fuzzy approach as a technique for evaluating paintings. The result showed that the fuzzy approach can be applied for evaluating paintings effectively and can provide artists with an idea of how to concentrate their efforts at the creation stage in order to communicate easily with their audience. The fuzzy approach seems to be a good way to provide a possible solution to this methodological problem (Carlesson \& Fullér 2003; Chen, Lin, \& Huang, 2006). 
The fuzzy approach appears to have an advantage over the subjective interpretation of confusion through matching tests because dimensions extracted through the fuzzy approach are the subjects' perceptions of the stimuli. Although the idea of using a confusion matrix in the fuzzy approach to explore the cognition of turning poetry into painting is quite simple, this study is merely the first step in testing the utility of fuzzy rating as a technique for understanding painting recognition and creation, and is clearly worthy of more in-depth study. It is suggested that the fuzzy approach be validated through more testing and evaluating of paintings in further study.

\section{References}

Antonietti, A., \& Cantoia, M. (2000). To see a painting versus to walk in a painting: An experiment on sense-making through virtual reality. Computers \& Education, 34, 213-223.

Barthelemy, K. K., Mazur, K. M., \& Reising, J. M. (1990). Color coding and size enhancements of switch symbol critical features. Proceedings of the Human Factors and Ergonomics Society Annual Meeting, 34(1), 99-103.

Barthes, R. (1967). Elements of semiology. (A. Lavers \& C. Smith, Trans.). London, U.K.: Jonathan Cape.

Beatty, E. L. (2011). The intersection of poetry and design. Paper presented at The Proceedings of the 8th ACM Conference on Creativity and Cognition, Atlanta, Georgia, USA.

Beatty, E. L., \& Ball, L. J. (2010). Poetic design: An exploration of the parallels between expert poetry composition and innovative design practice. Paper presented at The Proceedings of the 1st DESIRE Network Conference on Creativity and Innovation in Design, Aarhus, Denmark.

Beatty, E. L., \& Ball, L. J. (2011). Investigating exceptional poets to inform an understanding of the relationship between poetry and design. Paper presented at The Proceedings of the Second Conference on Creativity and Innovation in Design, Eindhoven, Netherlands.

Belke, B., Leder, H., Strobach, T., \& Carbon, C. C. (2010). Cognitive fluency: High-level processing dynamics in art appreciation. Psychology of Aesthetics, Creativity, and the Arts, 4(4), 214-222.

Carlesson, C., \& Fullér, R. (2003). A fuzzy approach to real option valuation. Fuzzy Sets and Systems, 139(2), $297-312$.

Chen, C. T., Lin, C. T. \& Huang, S. F. (2006). A fuzzy approach for supplier evaluation and selection in supply chain management. International journal of Production Economics, 102(2), 289-301.

Collins, B. L., \& Lerner, N. D. (1983). An evaluation of exit symbol visibility. Washington, D.C.: U.S. Department of Commerce, National Bureau of Standards; National Technical Information Service.

Fiske, J. (1990). Introduction to communication studies (2nd ed.). London, U.K.: Routledge.

Frankel, H. H. (1957). Poetry and paintings: Chinese and Western views of their convertibility. Comparative Literature, 9(4), 289-307.

Gentner, D., \& Stevens, A. L. (1983). Mental models. Hillsdale, N.J.: Erlbaum.

Hancock, P. A., \& Meshkati, N. (1988). Human mental workload (1st ed.). Amsterdam: North Holland.

Hsu, C. H., Chang, S. H., \& Lin, R. (2013). A design strategy for turning local culture into global market products. International Journal of Affective Engineering, 12(2), 275-283.

Hsu, C. H., Lin, C. L., \& Lin, R. (2011). A study of framework and process development for cultural product design. In P. L. P. Rau (Ed.), Internationalization, design and global development (Vol. 6775, pp. 55-64). Berlin: Springer.

Jakobson, R. (1987). Language in literature. Cambridge, M.A.: Belknap Press.

Klir, G. J. (2005). Uncertainty and information: Foundations of generalized information theory. Hoboken, N.J.: John Wiley \& Sons.

Kreifeldt, J., Lin, R., \& Chuang, M. C. (2011). The importance of "feel" in product design feel, the neglected aesthetic "Do Not Touch". In P. L. P. Rau (Ed.), Internationalization, design and global development (Vol. 6775, pp. 312-321). Berlin: Springer.

Laude, J., \& Denomme, R. T. (1972). On the analysis of poems and paintings. New Literary History, 3(3), 471-486.

Leder, H., Belke, B., Oeberst, A., \& Augustin, D. (2004). A model of aesthetic appreciation and aesthetic judgments. British Journal of Psychology, 95(4), 489-508.

Lin, R. (2007). Transforming Taiwan aboriginal cultural features into modern product design: A case study of a cross-cultural product design model. International Journal of Design, 1(2), 45-53. 
Lin, R. (1994). An application of fuzzy graphic rating in icon design. Mingchi Institute of Technology Journal, 26, 201-207.

Maré, E. A. (2010). Can one "read" a visual work of art? South African Journal of Art History, 25(2), 58-68.

Michel, K. F. (1999). Turning poetry into paintings: An experiment in visualization. Art Education, 52(3), 6-12.

Norman, D. A. (1988). The design of everyday things. New York, N.Y.: Doubleday.

Norman, D. A. (2004). Emotional design-Why we love or hate everyday things. New York, N.Y.: Basic Books.

Reber, R., Schwarz, N., \& Winkielman, P. (2004). Processing fluency and aesthetic pleasure: Is beauty in the perceiver's processing experience? Personality and Social Psychology Review, 8(4), 364-382.

Silverman, K. (1984). The subject of semiotics. New York, N.Y.: Oxford University Press.

Silvia, P. J. (2005). Emotional responses to art: From collation and arousal to cognition and emotion. Review of General Psychology, 9(4), 342-357.

Tiedens, L. Z., \& Linton, S. (2001). Judgment under emotional certainty and uncertainty: The effects of specific emotions on information processing. Journal of Personality and Social Psychology, 81(6), 973-988.

Worringer, W. (2007). Abstraction and empathy: A contribution to the psychology of style. Chicago, I.L.: Ivan R. Dee.

Yen, H. Y., Lin, C., \& Lin, R. (2013). Analysis of cognition difference of visual and imagined haptic inputs on product texture. In P. L. P. Rau (Ed.), Cross-cultural design: Methods, practice, and case studies (Vol. 8023, pp. 157-164). Berlin: Springer.

Yeh, M. L., \& Lin, P. H. (2014). Beyond claims of truth. Journal of Arts and Humanities, 3(1), 98-109.

Yeh, M. L., Lin, R., Wang, M. S., \& Lin, P. H. (2014). Transforming the hair color design industry by using paintings: From art to e-business. International Journal of E-Business Development, 4(1), 12-20.

Zwaga, H. J. (1989). Comprehensibility estimates of public information symbols: Their validity and use. Proceedings of the Human Factors and Ergonomics Society Annual Meeting, 33(15), 979-983. 